\title{
Pengaruh transaksional elit politik terhadap model komunikasi politik pilwalkot Serang 2018
}

\author{
Rangga Galura Gumelar', Ikhsan Ahmad², Iman Mukhroman ${ }^{3}$ \\ ${ }^{1,2.3}$ Universitas Sultan Ageng Tirtayasa, Serang, Indonesia
}

\begin{abstract}
ABSTRAK
Transformasi sistem sentralistik menjadi disentralistik adalah hasil perjuangan reformasi yang berdampak sangat besar bagi perubahan sistem pemerintahan yang ada di Indonesia. Ruang demokrasi lokal kemudian menjadi menarik untuk diikuti karena dinamika kontestasi politiknya semakin hidup melalui jalur partai politik tetapi juga menciptakan model kepemimpinan transaksional. Kekuatan modal telah berperan di setiap tahapan proses kontestasi. Tujuan dalam penelitian ini adalah untuk melihat bagaimana pengaruh transaksional elit politik terhadap model komunikasi politik dalam Pilwalkot Serang tahun 2018, dimana fokus perhatian pada penelitian ini tentunya melihat bagaimana proses demokrasi ini terbebas dari praktek-praktek transaksional yang dapat berpengaruh pada arah penurunan substansial demokrasi itu sendiri. Pendekatan penelitian ini menggunakan perspektif post-positivistik menggabungkan pada pendekatan kuantitatif dan kualitatif yang mengolah data berdarsarkan pada jumlah sampel yang telah ditentukan pada populasi yang ada. Analisis data dari hasil angket yang disebarluaskan pada sampel kemudian dilakukan analisis dengan menggunakan path analisis menjelaskan Komunikasi Politik merupakan faktor yang cukup penting dan memiliki peran yang signifikan Sedangkan ideologi partai politik memberikan gambaran yang sangat signifikan. Artinya ketika ideologi partai bersumber pada finansial, maka semuanya akan tergantung pada janji dan nilai transaksi politik yang diandalkan. Hasil Penelitian menunjukkan korelasi antara Komunikasi politik uang terhadap transaksional politik terbilang cukup kuat, artinya komunikasi Politik memiliki korelasi yang cukup tinggi terhadap transaksional politik. Demikian pula Korelasi Ideologi terhadap transaksional politik adalah kuat artinya parpol tidak memiliki kekuatan dan idealisme ketika berbenturan dengan dana atau kekuatan finansial. Sedangkan korelasi antara Komunikasi Politik, Ideologi, terhadap Transaksional Politik adalah kuat, artinya kekuatan transaksional yang dilakukan oleh para elit sudah sangat masif dan memiliki peran yang sangat kuat.
\end{abstract}

Kata-kata Kunci: Transaksional elit politik; model komunikasi; komunikasi politik; ideologi; pilwalkot Serang

\section{The influence of political elite transaction to the political communication model of mayor election of Serang 2018}

\begin{abstract}
Centralistic system transformation become decentralized is the result of Reformation that had a large impact for governmental system change in Indonesia. Local democracy space then become interesting to followed because the dynamic of political contestation is more alive through the path of political party but also had created a transactional leadership model. Capital strength has involved in every step of contestation process. The purpose of this study is to see how the transactional influence of political elites on the political communication model in the 2018 Serang City Mayor Election, where is our goal in this research is to see how this democratic process is free from transactional practices that can affect the direction of a substantial decline in democracy itself. The research approach used post- positivistic perspective that combined the quantitative and qualitative approach for data processing based on few samples that had determined in existing population. The data analysis from questionnaire that has been disseminated on sample then analyzed with analyzing path to describe political communication is important factor and has a significant role while political party ideology has given a significant clear image. That means when ideology of political party sourced on financial, then everything would depend on promises and reliable value of political transaction. The result of study shows correlation between money politics communication to political transaction is quite strong, which mean political communication has a quite high correlation with political transaction. On the other hand, the correlation between ideology and political transaction is strong on number. That means political party did not have power and idealism when facing fund or financial strength. Meanwhile the correlation between political communication, Ideology, with political transactional are strong, it means that transactional power which played by the elites is massive and has a strong role.
\end{abstract}

Keywords: Transactional of political elite; communication model; politic communication; ideology; mayor election

Korespondensi: Dr. Rangga Galura Gumelar, M.Si., Universitas Sultan Ageng Tirtayasa. Jl. Raya Jakarta Km. 4, Pakupatan, Serang, Banten.Email: rangga.gumelar@untirta.ac.id

Submitted: November 2019, Accepted: April 2021, Published: June 2021

ISSN: 2303-2006 (print), ISSN: 2477-5606 (online). Website: http://jurnal.unpad.ac.id/jkk

Terakreditasi Kemenristekdikti RI SK No. 48a/E/KPT/2017 


\section{PENDAHULUAN}

Perubahan sistem sentralistik menjadi disentralistik hasil perjuangan reformasi memberikan dampak yang sangat besar bagi perubahan sistem pemerintahan yang ada di Indonesia. Ruang demokrasi lokal kemudian menjadi menarik diikuti karena dinamika kontestasi politiknya semakin hidup dari jalur partai. Sejalan dengan otonomi daerah yang diatur dalam Undang-Undang Nomor 32 tahun 2004 tentang Otonomi Daerah yang kemudian di revisi menjadi Undang-Undang Nomor 23 tahun 2014 tentang Pemerintahan Daerah untuk mewujudkan kesejahteraan masyarakat daerah dan mengembangkan potensi-potensi daerah yang ada. Terbitnya Undang-Undang ini sebagai payung hukum dan dasar agar para pemimpin lokal untuk mengedepankan pada pelayanan dan peningkatan masyarakatnya.

Pemilihan langsung dan kebebasan berpendapat serta kebebasan berpolitik bagi setiap warganya saat ini masih menyisakan banyak persoalan dari perspektif kejujurannya. Kekuasaan menjadi pemimpin daerah tidak terlepas dari adanya sifat-sifat transaksional yang membutuhkan pada kekuatan modal sehingga terjadi suatu korelasi yang sangat jelas dimana kekuatan modal menjadikan indikator kuat dalam meraih dukungan khususnya untuk mendapatkan kursi dari partai yang mengusung. Dalam hal tersebut kekuasaan dan uang seakan menjadi sebuah kovalen yang juga memiliki fungsi sosial dimana menjadi fungsi acuan rata-rata bertingkah laku untuk memenuhi kebutuhan individu, keluarga, kelompok, masyarakat hingga organisasinya (Ahmad, 2015). Alasan kemudian dilakukan pemilihan secara langsung yaitu 1) Agar konsisten dengan sistem pemerintahan presidensial, dimana esensinya rakyat berhak menentukan siapa yang cocok menjadi pemimpinnya terutama dalam menentukan pola dan arah kebijakan yang mereka ambil demi terciptanya masyarakat yang sejahtera; 2) Sebagai upaya dalam rangka menciptakan struktur kekuasaan yang berimbang antara eksekutif dan legislatif (Surbakti,2007).

Akan tetapi pada prakteknya proses demokrasi ini membutuhkan biaya yang sangat tinggi dalam pelaksanaannya, proses pemilukada yang ada saat ini disinyalir sangat kental karena adanya proses transaksi dan berbiaya tinggi sehingga menghasilkan asumsi antara calon tersebut dengan masyarakatnya melakukan praktik jual beli suara dalam proses pemilukada tersebut (Kumorotomo, 2009). Dalam hal ini satu suara dari masyarakat dapat dijadikan sebagai sebuah komoditas yang sangat penting dalam pemilukada dimana memiliki nilai jual bagi para calon yang bertarung, dan jauh sebelumnya suara dari partai pengusung untuk calon yang akan bertarung sangat rentan terhadap bagaimana si calon tersebut memainkan kekuatan modalnya bagi partai yang mengusungnya.

Kompleksitas permasalahan juga dipengaruhi oleh Undang-Undang Republik Indonesia Nomor 10 Tahun 2016 tentang Perubahan Kedua Atas Undang-Undang Nomor 1 Tahun 2015 Tentang Penetapan Peraturan Pemerintah Pengganti Undang-undang Nomor 1 Tahun 2014 Tentang Pemilihan Gubernur, Bupati dan Walikota Menjadi UndangUndang dimana dalam pasal 40 (1) disebutkan bahwasanya partai politik atau gabungan partai politik dapat mendaftarkan pasangan calon jika telah memenuhi persyaratan perolehan paling sedikit 20\% dari jumlah kursi Dewan Perwakilan Rakyat Daerah atau 25\% dari akumulasi perolehan suara sah dalam pemilihan umum anggota Dewan Perwakilan Rakyat Daerah yang bersangkutan. Hal ini menjadi sangatlah sulit yang untuk sebuah partai mengusung calonnya sendiri sehingga dengan demikian harus tercipta sebuah koalisi pragmatis demi kepentingan sesaat untuk menggolkan pasangan tersebut. Selain dari itu calon yang diusung tentunya harus dapat mengkompromikan atas kepentingan-kepentingan dari partai pengusung tersebut, sehingga kontrak politik terasumsikan sebagai sebuah transaksional kepentingan jangka panjang. Dengan demikian demokrasi tidak seutuhnya bebas, dikarenakan memiliki ketergantungan yang besar pada kekuatan partai politik sebagai kendaraan politik (Sulaiman, 2013). Keadaan ini bukan saja hanya di Indonesia akan tetapi juga telah merambah pada seluruh dunia yang mengatasnamakan demokrasi.

Adanya transaksional dalam perjuangan menentukan sosok pemimpin, yang memiliki kepentingan yang sangat tinggi tentunya mencederai pada substansi demokrasi itu sendiri. Sifat transaksi tersebut yang merujuk padakekuatan modal yang kemudian terbungkus 
pada politik uang tentunya menyiratkan bagaimana proses pembentukan kepemimpinan yang seyogyanya dalam demokrasi dengan nilai kejujuran dan etika ini sangat tidak diharapkan, permainan money politic tidak dapat dihindari (Pratikno, 2007). Sangat berat tentunya hasil dari praktek ini menghasilkan sosok pemimpin yang mampu membuat terobosan dan kebijakankebijakan yang pro terhadap kepentingan rakyat yang seringkali bertentangan karena adanya kepentingan bersama yang telah disetujui dalam sebuah kesadaran berkelompok ataupun berkoalisi (Ahmad, 2015). Fenomena ini yang akhirnya sulit untuk mewujudkan sebuah harapan pesta demokrasi yang bebas dan adil untuk dilaksanakan, karena pada tahapan awal penentuan calon pemimpin yang diusung banyak disinyalir beririsan dengan praktek money politic. Pada akhirnya sebagai kepala daerah yang mengemban dua tugas berat yaitu sebagai pejabat publik dan juga sebagai pejabat politik, tidak dapat dilakukan dan dilaksanakan dengan semaksimal mungkin, karena tersandera pada sebuah proses konsensus dari partai pengusung termasuk pada kelompok atau elit di luar partai yang memiliki kontribusi atau sumber daya yang dapat meloloskan calon tersebut menjadi kandidat calon hingga pemenang pemilihan kepala daerah.

Model kepemimpinan yang kemudian dihasilkan dalam sebuah sistem yang memberikan ruang pada jalannya politik uang, pada dasarnya haruslah dihindari. Akan tetapi faktanya kejadian ini terus berlangsung dan bukan lagi menjadi sebuah rahasia umum akan tetapi telah menjelma sebagai sebuah pemahaman dalam kontes pemilihan kepala daerah di Indonesia. Selain dari itu penentuan calon kepala daerah, dalam mekanisme untuk mengusung kader lokal atau militan tidaklah mudah, dalam penelitian sebelumnya disebutkan bahwa seleksi calon pemimpin yang diusung oleh partai sangatlah ditentukan oleh kekuasaan partai di pusat, sehingga daerah atau kader partai lokal hanya bisa menentukan pada sebuah wacana calon, karena proses penetapan calon mutlak keputusan pusat dan sifatnya tertutup (Ahmad et al., 2017). Artinya pada perjalanan menuju kepemimpinan yang dimulai dari proses seleksi di kalangan partai hingga pada proses pemilihan langsung memiliki kecenderungan memainkan pada kekuatan politik uang, hal ini cukup kontradiktif karena fungsi partai politik sesungguhnya mencari dan mempertahankan kekuasaan untuk mewujudkan program berbasiskan pada ideologi tertentu (Sulaeman, 2017).

Pendekatan pada terciptanya pemimpin yang berlaku di Indonesia, khususnya di Kota Serang memberikan ruang dan tema yang menarik untuk di bahas. Pendekatan yang dilakukan oleh para calon yang maju tentunya dilakukan secara masif dalam upaya peneguhan keyakinan khususnya di kalangan partai politik dan umumnya di kalangan masyarakat, sebagai sosok pemimpin yang tepat dalam melangsungkan dan mengemban kekuasaan menjadi pasangan Walikota dan Wakil Walikota Serang. Komisi Pemilihan Umum (KPU) Daerah Kota Serang pada tanggal 12 Februari 2018 menetapkan Tiga pasangan calon yang akan bertarung memperebutkan posisi Walikota dan Wakil Walikota Serang periode 20182023. Kedua pasangan itu yaitu Vera Nurlaela didampingi Nurhasan, Syafrudin didampingi oleh Subadri diusung oleh partai politik, sementara pasangan Samsul dan Rohman dari indenpenden. Menjadi bahasan menarik karena pasangan Vera dan Nurhasan di usung oleh delapan (8) partai politik yakni Partai Golkar, PKB, PBB, PKPI, NasDem, Gerindra dan Demokrat. Sedangkan Pasangan Syafrudin dan Subadri di usung oleh empat (4) partai yaitu PAN, PKS, Hanura dan PPP. Jika dilihat bahwa sosok calon yang diusung bukanlah kader partai yang telah lama melintang, Vera Nurlaela walaupun kader Golkar akan tetapi lebih dikenal sebagai istri Walikota Serang Tb. Haerul Jaman, sedangkan Syafrudin merupakan PNS aktif yang kemudian mengundurkan diri untuk menjadi calon walikota, yang artinya praktis dalam kesehariannya tidak boleh melakukan politik praktis karena statusnya sebagai Aparatur Sipil Negara (ASN). Jika melihat pada kenyataan ini, maka akan timbul sebuah diskursus bagaimana kemudian sosok mereka dipilih oleh partai sebagai calon pemimpin yang akan berlaga pada pertarungan pilwalkot Serang 2018-2023.

Menjadi sebuah pertanyaan besar yang kemudian harus segera diberikan solusinya pada sosok pemimpin yang kemudian terpilih sebagai sebuah proses seleksi calon yang terasumsikan dalam sebuah paradigma berpikir transaksional yang berakibat pada hancurnya subtansial demokrasi yang dilaksanakan. Oleh karenanya dalam sistem demokrasi dan aturan 
yang seakan carut marut ini, studi ini mencoba membuat sebuah model kepemimpinan yang kemudian terafiliasi pada jalur transaksional dalam pembangunan substansi demokrasi. Pelaksanaan demokrasi pada pemilukada sangat sarat dengan bagi-bagi uang untuk menggaet suara rakyat melalui simpatisan, keluarga, relawan yang mendukungnya (Aminuddin \& Attamimi, 2019). Siapapun yang menjadi pemenang sesungguhnya hanya sebuah ilustrasi pemaksaan terhadap calon yang disuguhkan kepada masyarakat, tanpa masyarakat mampu memberikan alternatif lain siapa yang sesungguhnya sesuai dengan kriteria dan kebutuhan dari wilayah Kota Serang tersebut. Bagaimana para pasangan ini hingga kemudian bertarung dan ditetapkan sebagai pemenang dalam kompetisi Pilwalkot, merupakan bentuk konstruksi politik yang telah didesain sebagai bentuk kepentingan partai politik tersebut. Pergerakan para elit dalam membangun komunikasi politik membangun sebuah paradigma dan keputusan yang baik secara sadar atau tidak sadar masyarakat harus mau menerimanya. Praktik politik yang berlaku saat ini, dan hampir berkembang di seluruh wilayah Indonesia memberikan sebuah gambaran jelas pada kita bagaimana transaksi politik tersebut terjalin.

Komunikasi politik dapat dinyatakan sebagai sebuah proses dengan hasil raihan yang maksimal dan langkah terbaik (Kaid, 2004), selain dari itu komunikasi politik merupakan hasil kombinasi antara pengetahuan dan seni dalam prakteknya (Kenterelidou, 2005). Pendekatan komunikasi yang sesuai pada penerapan komunikasi politik adalah model komunikasi Lasswell yang bersifat linear (Lasswell, 1948), terdiri dari Who Says What, To Whom, In Which Channel, and What Effect. Laswell memandang bahwa efek atau keberhasilan dari sebuah komunikasi sangat tergantung pada bagaimana proses komunikasi itu dilakukan. Pengembangan pada model Lasswel ini, ternyata bukan saja dalam komunikasi yang sederhana atau linear semata, akan tetapi model ini dapat digunakan pada tataran komunikasi politik, karena pada tataran ini akan berusaha secara serius pada arah untuk mencapai tujuan yang ditetapkan (Nimmo, 1978). Tujuan yang menjadi kesepakatan bersama, dalam kenyataannya untuk meraih tujuan tersebut memiliki biaya yang sangat besar. Tujuan dalam komunikasi politik itu sendiri bukan dalam konteks jangka pendek semata, akan tetapi dalam proses jangka panjang. Kekuasaan politik akan selalu dipelihara dengan baik, karena bagaimanapun berada dan mengendalikan kekuasaan tentunya memberikan kenyamanan tersendiri dan bagi orang-orang yang berada di lingkaran kekuasaan tersebut.

Komunikasi politik dibangun dalam bentuk pragmatis, oleh sebab itu bahasan dalam komunikasi politik selalu memunculkan pada karakteristik dan identitas keilmuan itu sendiri yang bersifat ilmu murni (pure science) yang berati ideal yang masuk dalam lingkup das Sollen dan das Sein. Oleh sebab itu keterkaitan pada setiap elemen pada model Laswell sangatlah penting, yaitu: a) Who Says What (Komunikator Politik Berbicara Pesan) merupakan bagian penting yang memberi warna dominan terhadap proses komunikasi, dalam konteks ini jika kemudian kita gambarkan komunikator berada pada struktur kekuasaan, yang sekiranya dapat mengelola, mengendalikan lalu lintas transformasi pesanpesan komunikasi serta bagaimana mereka menggiring pada suatu wilayah ataupun cakupan yang sesuai dengan kepentingannya; b) To Whom (Komunikan), Perilaku pemilih dalam menentukan pasangan mana yang dipilih saat ini dengan kedewasaan berpikir dan kebebasan memilih dapat dikategorikan sebagai pemilih yang cerdas. Masyarakat tidak akan langsung percaya terhadap apa yang disampaikan oleh komunikator politik, akan tetapi dilakukan analisis terhadap pesan yang ada; c) In Which Channel (Media), apa yang kemudian digunakan dalam proses penyampaian pesan ini sangat penting; d) What Effect (Efek), yang kemudian dihasilkan dari adanya pendekatanpendekatan yang dilakukan. Jika kemudian kita sederhanakan, bahwasanya efek akan bernilai positif jika para pemilih sesuai dan cocok untuk memilih pasangan yang bertarung.

Ideologi sangatlah penting karena memiliki fungsi sebagai sebuah keteguhan dalam menanamkan keyakinan bagi para anggotanya. Ideologi partai politik sangatlah penting karena akan dijadikan sebagai pegangan dan acuan dalam individunya untuk melakukan halhal yang akan mereka kerjakan (Andriana, 2016). Sebagai sebuah lembaga, maka partai politik memiliki ideologi yang menjadi 
landasan dalam membuat aturan dan tata cara pelaksanaan partai. Ideologi partai ini akan bertransformasi menjadi sebuah dogma bagi para kadernya, karena dalam ideologi tersebut akan tersirat cita-cita dan capaian yang akan diperjuangkan oleh para kader partai tersebut. Akan tetapi, prakteknya koalisi yang dibangun khususnya menjelang pilkada tidak lagi terbentuk dalam kesamaan ideologi semata, akan tetapi terbangun atas tujuan pemenangan semata. Mahalnya biaya yang harus dikeluarkan dalam pemilihan tersebut maka ideologi yang kemudian tercipta secara bersama-sama di partai politik adalah ideologi kapitalisme. Ideologi yang bersumberkan pada ketentuan kekuatan ekonomi dan sumber daya semata, untuk satu tujuan yaitu memenangkan pertarungan dalam perebutan atau pelanggengan kekuasaan. Sehingga dalam konteks ini, sangatlah jelas kekuatan kapital sangat menentukan bagaimana kemudian mereka bertarung. Ongkos dan beban dari pemilukada sebagai sebuah legalisasi yang benar dalam menentukan pemimpin yang sah menurut aturan yang berlaku, pada akhirnya tersandera pada transaksi-transaksi kepentingan yang berujung pada kekuatan modal. Untuk dapat menggerakkan mesin partai harus didukung oleh dana yang besar, oleh karenanya partai sangat tergantung pada kekuatan uang dimana kekuatan tersebut berada pada elit-elit partai politik tersebut (Reuter, 2015).

Beberapa studi empiris memperlihatkan bagaimana proses transaksional di pemilukada melahirkan pada sebuah fenomena yang memiliki kecenderungan negatif seperti halnya melahirkan para pemimpin yang tersandera oleh kasus hukum seperti halnya korupsi (Solihah, 2016), melahirkan praktek money politic yang tidak sesuai dengan kaidah demokrasi dan bertentangan dengan hukum (Ali, 2003), selain dari itu transaksional money politic melahirkan sebuah fenomena relasi dari masyarakat dan calonnya, karena harus disadari bahwa pemilihan langsung tidak selalu dapat mengandalkan pada partai pengusung akan tetapi harus dibangun langsung kepada pemilih (Aminuddin \& Attamimi, 2019). Berdasarkan penjelasan dan permasalahan tersebut, maka tujuan dalam penelitian ini adalah untuk melihat bagaimana pengaruh transaksional elit politik terhadap model komunikasi politik dalam Pilwalkot Serang tahun 2018. Adapun fokus perhatian pada penelitian ini tentunya melihat bagaimana proses demokrasi ini terbebas dari praktek-praktek transaksional yang dapat berpengaruh pada arah penurunan substansial demokrasi itu sendiri. Kekuatan modal yang sangat besar berperan dalam setiap proses baik dari proses awal, penjaringan, penetapan dan kampanye itu sendiri. Penelitian ini diharapkan bermanfaat sebagai sumbangan berupa temuantemuan yang dapat menjadi titik awal bagi penelitian komunikasi politik, lebih khusus bagi pengembangan kajian politik dalam konteks pengembangan dan pembelajaran pada sistem demokrasi yang saat ini dilaksanakan pada penetapan pemimpin daerah. Oleh karenanya diperlukan sebuah pengukuran terkait sejauh mana komunikasi politik dan ideologi partai berpengaruh pada proses transaksional. Berikut adalah hipotesis yang diuji dalam penelitian ini:

\section{H1: Komunikasi Elit Politik berpengaruh terhadap transaksional \\ H2: Ideologi berpengaruh terhadap transaksional \\ H3: Komunikasi Elit Politik dan Ideologi berpengaruh pada transaksional.}

\section{METODE PENELITIAN}

Penelitian ini menggunakan dua pendekatan, yaitu pendekatan secara kuantitatif dan pendekatan secara kualitatif atau yang sering disebut dengan penelitian mix methods. Kekuatan dari mix methods ini adalah dengan cara menggabungkan metode observasi dan wawancara mendalam yang merupakan data kualitatif, digabungkan dengan menggunakan metode survei tradisional yang merupakan data kuantitatif (Creswell, 2014).

Teknik pengumpulan data terdiri dari 2 (dua) kategori yaitu data primer dan data sekunder. Data primer diperoleh langsung dari objek yang diamati, melalui: (1) Kuisioner; (2) Observasi; (3) Wawancara, baik dengan menggunakan teknik wawancara terstruktur ataupun tidak terstruktur. Skala pengukuran yang digunakan yaitu skala Likert untuk mengukur sikap, pendapat, dan persepsi seseorang atau kelompok orang tentang fenomena sosial (Sugiyono, 2018). Setiap pernyataan yang di isi oleh responden kemudian akan diberi nilai sebagai berikut: Sangat Setuju (SS), yang memiliki skor 4, Setuju (S), yang memiliki skor 
3, Tidak Setuju (TS), yang memiliki skor 2, Sangat Tidak Setuju (STS), yang memiliki skor 1 .

Untuk dapat melakukan analisis data, maka harus dilakukan penentuan populasi, dimana populasi penelitian adalah keseluruhan atau elemen yang memiliki ciri atau karakteristik yang dapat dijadikan sebagai objek penelitian ini (Muhidin \& Abdurahman, 2007). Adapun yang menjadi populasi pada penelitian ini adalah mereka yang merupakan kader atau anggota partai pengusung pasangan Vera dan Nurhasan yaitu dari Partai Golkar dan anggota partai pengusung pasangan Syafrudin dan Subadri dari Partai Amanat Nasional (PAN). Alasan pemilihan kedua partai ini, didasarkan pada keberadaan sebagai pengusung pasangan yang bertarung dalam Pilwalkot Serang 2018. Dalam penentuan sampel ini, peneliti kemudian memberikan batasan-batasan terkait dengan sumber daya yang peneliti miliki. Penelitian menggunakan sampling kuota, dimana sampel yang diambil dalam penelitian ini sebanyak 60 orang, yang kemudian terbagi dari masingmasing partai pengusung calon Walikota dan Wakil Walikota Serang periode 2018-2023. Dengan fokus pada sampel di atas, selain dengan penyebaran kuesioner penelitian ini pun mengajukan pertanyaan-pertanyaan dengan lebih fokus pada pendalaman di wawancara bersama para elit politik dari kedua partai tersebut. Informan penelitian adalah orang yang dimanfaatkan untuk memberikan informasi tentang situasi dan kondisi latar belakang peneliti (Moleong, 2018). Informan merupakan orang yang benar-benar mengetahui permasalahan yang akan diteliti. Adapun informan yang dimaksud adalah mereka yang aktif di kepengurusan anggota partai dan mereka yang memiliki jabatan dan pengaruh besar dalam Partai Golkar dan PAN. Pelaksanaan penelitian dilakukan pada bulan September hingga bulan November 2018, setelah dilaksanakannya proses Pilwalkot Serang yang dilaksanakan pada bulan Juli 2018.

Pengaruh komunikasi politik dan ideologi terhadap proses transaksional calon pemimpin pada studi kasus Pilwalkot Serang periode 20182023 dapat dilihat secara konseptual dengan menguji variabel independen (X1) Komunikasi Politik, (X2) Ideologi, dan variabel dependen (Y) Transaksional. Untuk menguji keabsahan data maka dilakukan pengukuran validitas dan reliabilitas data dengan menggunakan sampel sebanyak 30. Uji validitas pengujiannya dengan cara menghitung korelasi pada masing-masing pernyataan pada kuesioner dengan skor total dengan menggunakan rumus teknik corelation product moment (Sugiyono, 2018), sedangkan menguji apakah kuesioner itu dapat dikatakan reliabel apabila hasil uji statistik Alpha $\alpha>$ 0,60, (Ghozali, 2006), dimana tingkatan reliabel dimulai dari 0,00-0,20 (Kurang Reliabel); $>0,20-0,40$ (Agak Reliabel); >0,40-0,60 (Cukup Reliabel); >0,60-0,80 (Reliabel); dan >0,801,00 (Sangat Reliabel) (Sugiyono, 2012)

Analisis deskripsi digunakan untuk mendeskripsikan secara lengkap dan akurat tentang pokok peneitian, yaitu: Komunikasi Politik $\left(\mathrm{X}_{1}\right)$; Ideologi $\left(\mathrm{X}_{2}\right)$; Transaksional (Y) sedangkan analisis statistik inferensial, dilakukan untuk menguji hipótesis mencari hubungan sebab dan akibat dalam pengukurannya. Tingkat hubungan/korelasi dapat dinyatakan dari 0,00-0,199 (Sangat rendah); 0,2-0,399 (Renda); 0,4-0,59 (Sedang); 0,6-0,799 (Kuat); dan 0,8-1,00 (Sangat Kuat) (Sugiyono, 2012). Sedangkan untuk menguji hipotesis dilakukan dua pengujian yaitu uji $t$ dan uji F, dimana jika kedua nilai tersebut jika di bandingkan dengan nilai besar maka hipotesis diterima. Adapun dalam pengolahan data ini menggunakan software SPSS IBM versi 21.

\section{HASIL DAN PEMBAHASAN}

Hasil pengujian pada validitas data diambil dari sampel sebanyak 30 responden, didapatkan bahwa nilai korelasi product moment $\left(\mathrm{r}_{\text {hitung }}\right)$ untuk setiap pernyataan pada variabel bebas/ independen Komunikasi Politik (X1) sebanyak 10 pernyataan, Ideologi (X2) sebanyak 7 pernyataan dan variabel terikat/dependen Transaksional (Y) sebanyak 9 pernyataan dibandingkan dengan $\mathrm{r}_{\text {table, }}$, dengan taraf kesalahan $5 \%$, sebesar 0,36 dinyatakan valid dikarenakan jumlahnya melebihi $r_{\text {hitung }}>r_{\text {tabel. }}$ Sedangkan pada uji reliabilitas yang melihat pada tingkat keandalan kuesioner tersebut, nilai Cronbach's Alpha untuk Komunikasi Politik (X1) sebesar 0,78, Ideologi (X2) sebesar 0,71 dan Transaksional (Y) sebesar 0,68. Dari ketiganya nilai Cronbach's Alpha $>0,6$ maka semua butir yang ada dalam kuesioner reliabel. Berdasarkan pada hasil data yang didapatkan dari 60 responden, maka sebaran data dapat 
Tabel 1 Umur Responden

\begin{tabular}{ccc}
\hline Umur & $\mathrm{f}$ & $\%$ \\
\hline $20-30$ & 10 & $17 \%$ \\
$30-40$ & 21 & $35 \%$ \\
$40-50$ & 25 & $42 \%$ \\
$50-60$ & 4 & $25 \%$ \\
Jumlah & 60 & $7 \%$ \\
\hline
\end{tabular}

Sumber : Hasil Pengolahan Data SPSS IBM Versi 21, 2018

terlihat pada tabel 1 .

Berdasarkan pada Tabel 1, dapat dilihat usia responden pada penelitian ini paling banyak di berada pada kisaran usia 40 hingga 50 tahun, sebanyak $42 \%$ yang disusul oleh rentang usia 30-40 tahun sebesar 35\%. Hal ini menunjukkan bahwa dominasi partai saat ini lebih menitikberatkan pada politikus usia-usia muda. Usia 30 hingga 50 adalah usia dengan segala pengalaman sebagai anggota partai yang mumpuni. Paradigma partai saat ini telah banyak mengalami transformasi, dimana faktor penentu pada pemilukada saat ini didominasi oleh para kaum milenial. Artinya dalam perekrutan anggotanya, partai menitikberatkan pada mereka yang memiliki jaringan kepada kaum milenial. Selain dari itu secara terbuka partai mencoba menghilangkan kesan sebagai bagian produk lama yang memiliki historis pada pelanggengan kekuasaan seperti orde baru, oleh sebab itu baik saat ini di daerah banyak posisi strategis yang ada di partai diisi oleh para kaum muda. Walaupun jika ditarik kembali pada relasi yang yang ada, ternyata para kaum muda yang menempati struktur kekuasaan di partai tersebut memiliki relasi baik kerabat, saudara, keluarga dari para senior atau kader partai lamanya. Artinya transformasi partai masih berbasiskan pada trah.

Responden dalam penelitian ini lebih didominasi dari kalangan pria. Hal ini dikarenakan bahwa pada partai politik PAN dan Golkar di Kota Serang lebih banyak didominasi oleh pria. Walaupun, ketua umum Golkar Kota Serang diduduki oleh seorang perempuan, akan tetapi tetap mayoritas dikuasai oleh kaum pria. Pergerakan dan pendekatan yang dilakukan oleh pria masih dianggap lebih fleksibel dibandingkan dengan kaum perempuan. Walaupun Banten dapat dikatakan sebagai daerah yang kental akan kekuatan agama dan budayanya, akan tetapi Banten tidaklah anti pada kepemimpinan kaum perempuan, terbukti dengan adanya kepala daerah serta ketua umum partai politik baik di tingkat Kabupaten/ Kota atau Provinsi yang perempuan. Artinya secara genealogi kaum perempuan di Banten telah melek politik, walaupun memang secara persentase jumlah mereka masih jauh dari lakilaki.

Pada tabel 2, rata-rata dari responden berada pada angka 3,18 yang artinya bahwa responden menyatakan setuju variabel komunikasi politik adalah merupakan hal yang sangat penting terutama dalam konteks penentuan calon yang diusung dengan persentase $78,2 \%$. Akan tetapi $21,8 \%$ dari responden menyatakan ketidakpuasan pada proses komunikasi politik yang dilakukan, dikarenakan hasil dari calon yang kemudian ditetapkan seringkali bukan dari kader internal yang dianggap militan. Ria-riak dalam penentuan calon yang di usung seringkali menjadi permasalahan dan perpecahan bagi kader yang merasa pasangannya tidak diusung oleh partai. Akan tetapi, hingga saat ini walaupun hasil keputusan partai pada calon yang diusung tidak sesuai dengan harapan para kader, tetapi tidak menyurutkan mereka untuk keluar dari partai. Akan tetapi berdasarkan pada hasil data, banyak dari para kader yang masih ragu atas komitmen para calon terhadap partai sehingga berimbas pada kurang optimalnya mereka dalam melakukan kampanye atau pemenangan calon yang diusung.

Pada tabel 3, rata-rata dari responden berada pada angka 3,03 yang artinya bahwa responden menyatakan $76 \%$ setuju variabel ideologi adalah merupakan hal penting terutama dalam konteks penentuan calon yang diusung. Bagaimanapun para kader, menginginkan adanya calon yang di pilih dari internal dibandingkan eksternal. Walaupun pada faktanya tidak seperti tersebut. Para kader sangat menyadari bahwa calon yang diusung berdasarkan pada kesepakatan koalisi dibangun atas fondasi besarnya modal yang dimiliki, hal ini yang banyak disayangkan oleh para kader. Akan tetapi ketika kemudian mereka dihadapkan pada besarnya biaya yang dihadapkan pada pemilukada, maka nilainilai idealisme tersebut hilang terlebih ketika keputusan partai telah di tetapkan dan menjadi sebuah mandat untuk seluruh kader tanpa terkecuali. 


\begin{tabular}{|c|c|c|c|}
\hline No & Item Pernyataan & Mean & Median \\
\hline Q1 & $\begin{array}{l}\text { Sebagai kader, anda merasa bahwa penetapan } \\
\text { calon yang diusung oleh partai telah sesuai dengan } \\
\text { mekanisme dankebutuhan partai seta memberikan } \\
\text { keyakinan untuk memperjuangkannya }\end{array}$ & 3,51 & 4 \\
\hline Q2 & $\begin{array}{l}\text { Gerakan mengusung kandidat calon, apakah } \\
\text { didasarkan pada kemampuan finansial dari sang } \\
\text { kandidat tersebut }\end{array}$ & 3,31 & 3 \\
\hline Q3 & $\begin{array}{l}\text { Pendekatan yang dilakukan oleh kandidat calon } \\
\text { kepada partai lebih condong melalui pendekatan } \\
\text { finansial dibandingkan dengan mensosialisasikan } \\
\text { program-programnya kepada masyarakat }\end{array}$ & 2,91 & 3 \\
\hline Q4 & $\begin{array}{l}\text { Tidak ada masalah jika kemudian calon Walikota } \\
\text { dan Wakil Walikota yang diusung bukan } \\
\text { merupakan kader partai }\end{array}$ & 3,15 & 3 \\
\hline Q5 & $\begin{array}{l}\text { Keputusan pusat dalam penetapan calon } \\
\text { seringkali bertentangan pada aspirasi kader partai } \\
\text { di daerah }\end{array}$ & 3,38 & 3 \\
\hline Q6 & $\begin{array}{l}\text { Penjaringan yang dilaksanakan oleh partai, } \\
\text { dirasakan kurang mengakomodir peluang kader } \\
\text { untuk dapat berkompetisi }\end{array}$ & 3,2 & 3 \\
\hline Q7 & $\begin{array}{l}\text { Kandidat yang ditetapkan oleh partai, merupakan } \\
\text { orang-orang yang memberikan harapan besar } \\
\text { pada perubahan di Kota Serang }\end{array}$ & 3,05 & 3 \\
\hline Q8 & $\begin{array}{l}\text { Kandidat yang ditetapkan, anda yakini tidak akan } \\
\text { meninggalkan partai yang mengusungnya }\end{array}$ & 3,05 & 3 \\
\hline Q9 & $\begin{array}{l}\text { Pasangan yang kemudian ditetapkan oleh } \\
\text { partai, meyakinkan kepada anda untuk } \\
\text { mengkampanyekan untuk datang dan melakukan } \\
\text { pencoblosan terhadap kandidat tersebut }\end{array}$ & 3,06 & 3 \\
\hline \multirow[t]{2}{*}{ Q10 } & $\begin{array}{l}\text { Para partai politik di Pilwalkot Serang saat ini } \\
\text { telah melakukan komunikasi politik yang sangat } \\
\text { baik demi terlaksananya pemilukada yang jujur, } \\
\text { adil dan demokratis }\end{array}$ & 3,21 & 3 \\
\hline & Rata-Rata & 3,18 & 3,1 \\
\hline
\end{tabular}

Sumber : Hasil Pengolahan Data SPSS IBM Versi 21, 2018

Pada tabel 4, rata-rata jawaban responden terkait dengan transaksional berada pada angka 3,08 yang artinya transaksional di politik itu selalu ada. $77,13 \%$ menyatakan bahwa proses transaksional dalam pilwalkot Serang 20182023 masih terjadi dan dirasakan dinamikanya sangat tinggi, walau harus diakui bahwa pada periode ini masyarakat lebih antusias dibandingkan pada tahun-tahun sebelumnya. Hal positif yang dapat tergambar dari data di atas adalah bahwa telah ada bentuk perlawanan atau ketidaksetujuan terhadap keadaan dimana semuanya harus berdasarkan pada sifat transaksional. Artinya para kader secara sadar bahwa kemampuan finansial adalah modal untuk dapat di usung, akan tetapi jika penentuan calon selalu berdasarkan pada sifat transaksional para kader akan mencari alternatif lain karena pada dasarnya mereka merasa hak politiknya tidak tersalurkan dengan baik. 
Tabel 3 Analisis Variabel Ideologi

\begin{tabular}{|c|c|c|c|}
\hline No & Item Pernyataan & Mean & Median \\
\hline Q1 & $\begin{array}{l}\text { Walaupun bukan merupakan kader partai, akan tetapi } \\
\text { kandidat yang diusung akan memiliki keyakinan dan } \\
\text { ideologi yang sejalan dengan ideologi partai pengusung }\end{array}$ & 3,26 & 3 \\
\hline Q2 & $\begin{array}{l}\text { Kandidat yang diusung oleh partai politik memiliki } \\
\text { kemampuan yang baik serta sesuai dengan kebutuhan } \\
\text { dan profesionalisme }\end{array}$ & 3,11 & 3 \\
\hline Q3 & $\begin{array}{l}\text { Penentuan dan pengusungan kandidat calon Walikota } \\
\text { dan Wakilnya dalam proses murni, tidak dikarenakan } \\
\text { adanya mahar atau uang yang dijanjikan kepada partai } \\
\text { politik pengusung }\end{array}$ & 3,1 & 3 \\
\hline Q4 & $\begin{array}{l}\text { Koalisi partai saat ini, didasarkan pada kesamaan } \\
\text { ideologi, bukan berdasarkan pada kebutuhan pragmatis }\end{array}$ & 2,71 & 3 \\
\hline Q5 & $\begin{array}{l}\text { Sosok yang diusung merupakan sosok yang } \\
\text { tidak memiliki cacat ataupun bermasalah dalam } \\
\text { kehidupannya, yang mungkin saja memiliki implikasi } \\
\text { pada keyakinan masyarakat }\end{array}$ & 2,86 & 3 \\
\hline Q6 & $\begin{array}{l}\text { Faktor program serta janji yang disampaikan dan } \\
\text { diajukan oleh para kandidat merupakan hal penting } \\
\text { dan menjadi pertimbangan bagi partai politik }\end{array}$ & 3,05 & 3 \\
\hline Q7 & $\begin{array}{l}\text { Sosok yang diusung merupakan sosok yang memiliki } \\
\text { intergritas dan jauh dari korupsi }\end{array}$ & 3,16 & 3 \\
\hline & Rata-rata & 3,03 & 3,0 \\
\hline
\end{tabular}

Sumber : Hasil Pengolahan Data SPSS IBM Versi 21, 2018

Berdasarkan pada uji korelasi pada tabel 5 maka hubungan antara 1) Komunikasi Politik terhadap Transaksional Politik cenderung mengarah pada kuat dengan pengaruh $32,6 \% ; 2$ ) Ideologi Politik terhadap Transaksional Politik memiliki hubungan kuat dengan pengaruh 47,6\%, serta 3) Komunikasi Politik dan Ideologi Politik terhadap Transaksional Politik memiliki hubungan kuat, artinya indikator Komunikasi Politik dan Ideologi Politik kemudian menyebabkan adanya pola dan upaya transaksi Politik. Nilai signifikan $\mathrm{X} 1=0,00$ dan $\mathrm{X} 2=0,034$ dimana keduanya di bawah 0,05 , maka dapat disimpulkan bahwa kedua variabel ini memiliki pengaruh signifikan terhadap Y. Besarnya nilai $R$ Square yang merupakan hasil perhitungan, menunjukkan pada angka 0,67 , hal ini menunjukan bahwa sumbangan pengaruh X1 (Komunikasi Politik) dan X2 (Ideologi Politik) terhadap Y (Transaksional Politik) sebesar $44,8 \%$, sementara 45,2\% merupakan kontribusi dari variabel-variabel lain. Oleh karenanya dapat kemudian kita hitung nilai e1 dengan menggunakan rumus e1 $=\sqrt{ }(1-0,448)=0,55$. Dengan demikian akan diperoleh gambar 1.

Untuk menjawab hipotesis pertama dalam penelitian antara variabel X1 (Komunikasi Politik) terhadap variabel Y (Transaksional) didapatkan nilai t-hitung 3,639 > t-tabel 1,6, dan F-Hitung 23,6 > F-Tabel 3,15 artinya komunikasi Elit Politik berpengaruh terjadinya proses transaksional. Pada pengujian hipotesis kedua antara variabel Ideologi (X2) dan Variabel Y (Transaksional) didapatkan nilai t-hitung 4,208 > t-tabel 1,6, dan F-Hitung 29,3 > F-Tabel 3,15, yang berati Ideologi berpengaruh pada transaksional. Sedangkan pada pengujian hipotesis ketiga variabel X1 (Komunikasi Politik), Ideologi (X2) dan Variabel Y (Transaksional) didapatkan nilai t-hitung 4,161 > t-tabel 1,6, dan F-Hitung 32,7 > F-Tabel 3,15, yang artinya Komunikasi Elit Politik dan Ideologi berpengaruh pada transaksional. Melihat pada hasil uji hipotesis 


\begin{tabular}{|c|c|c|c|}
\hline No & Item Pernyataan & Mean & Median \\
\hline Q1 & $\begin{array}{l}\text { Calon yang diusung dalam pilwalkot Serang } 2018 \text {, } \\
\text { menjanjikan sesuatu kepada partai }\end{array}$ & 3,16 & 3 \\
\hline Q2 & $\begin{array}{l}\text { Penentuan pada calon yang diusung partai } \\
\text { didasarkan pada jumlah uang yang diberikan } \\
\text { kepada partai }\end{array}$ & 3,16 & 3 \\
\hline Q3 & $\begin{array}{l}\text { Penentuan pada keputusan calon yang diusung, } \\
\text { berdasarkan pada pengaruh dari beberapa elit partai }\end{array}$ & 2,08 & 3 \\
\hline Q4 & $\begin{array}{l}\text { Partai bekerja secara optimal dalam pemenangan, } \\
\text { walaupun calon yang diusung bukan dari kader }\end{array}$ & 2,18 & 3 \\
\hline Q5 & $\begin{array}{l}\text { Penentuan saya mendukung calon yang diusung } \\
\text { berdasarkan pada keputusan partai }\end{array}$ & 3,1 & 3 \\
\hline Q6 & $\begin{array}{l}\text { Walaupun saya mengetahui bahwa penentuan calon } \\
\text { yang diusung oleh partai berdasarkan pada tingkat } \\
\text { finansial, akan tetapi saya yakin itu merupakan } \\
\text { pilihan yang tepat }\end{array}$ & 3,15 & 3 \\
\hline Q7 & $\begin{array}{l}\text { Kemampuan finansial adalah hal utama dan penting } \\
\text { dalam menghadapi pemilu }\end{array}$ & 3,06 & 3 \\
\hline Q8 & $\begin{array}{l}\text { Praktik politik praktis saat ini tidak akan terlepas } \\
\text { dari praktek uang }\end{array}$ & 3,1 & 3 \\
\hline \multirow[t]{2}{*}{ Q9 } & $\begin{array}{l}\text { Penentuan calon yang bukan kader, merupakan hal } \\
\text { biasa dalam pilkada sehingga sebagai kader partai } \\
\text { saya tidak merasakan masalah }\end{array}$ & 2,75 & 3 \\
\hline & Rata-rata & 3,08 & 3,00 \\
\hline
\end{tabular}

Sumber : Hasil Pengolahan Data SPSS IBM Versi 21, 2018

maka dapat dikatakan bahwa semua hipotesis yang di ajukan di terima.

Dengan demikian secara sadar bahwa kader partai mengetahui untuk dapat bersaing dan menjadi calon atau kandidat tertentu dalam suatu posisi akan tergantung dari kemampuan sumber daya diantaranya kemampuan finansial. Akibatnya para kader hanya akan menerima hasil dari kompromi politik para elit yang memegang arus kekuasaan di partai, dikarenakan hal tersebut merupakan bagian dari kesepahaman dan patron doktrin yang disampaikan kepada kader partai. Implikasi krisis praktek politik uang terhadap penetapan pemimpin daerah yang dilakukan para elit politik memunculkan adanya dugaan kekuatan suap yang telah sekian lama sekarang menjadi kekuatan budaya. Pemilukada adalah bagian dari demokrasi dimana menganut asas dan sistem ketatanegaraan yang paling baik (Huda, 2011), akan ter cederai jika dalam pelaksanaannya melakukan sebaran relasi kekuasaan oleh segelintir elit politik dalam permainan sebaran modal. Akibat dari permainan para elit, memberikan skeptisme pada perspektif masyarakat pada penetapan calon yang diusung oleh partai politik (Susanto, 2013). Politik uang berimplikasi kepada hilangnya substansi konsensus atas nilai-nilai keteladanan dari semua unsur kekuatan demokratis, terutama partai politik dalam pembangunan yang diperlukan, kecuali hanya mengisi ruang-ruang formal dan deklarasi. Penentuan kandidat yang didapatkan melalui pendekatan uang akan berimplikasi pada kualitas dari pemimpin itu sendiri. Ada korelasi yang sangat jelas ketika pemimpin kualitasnya terbentuk pada pola uang, maka pendekatan kepada masyarakat pun akan melalui pendekatan uang. Ada pemakluman umum, bahwa setelah jadi pasti 
Tabel 5 Hubungan antar Variabel

\begin{tabular}{|c|c|c|c|c|c|c|}
\hline No & Uji Hipotesis & $\begin{array}{l}\mathrm{N} \text { i } 1 \text { a i } \\
\text { Korelasi }\end{array}$ & $\begin{array}{l}\text { U k u r a n } \\
\text { Korelasi }\end{array}$ & $\begin{array}{l}\text { Ko efisien } \\
\text { Determinasi }\end{array}$ & Nilai t & Nilai F \\
\hline 1 & $\begin{array}{l}\text { Komunikasi Politik }(\mathrm{X} 1) \\
\text { terhadap Transaksional Politik } \\
(\mathrm{Y})\end{array}$ & 0,57 & Cukup & $32,6 \%$ & 3,639 & 23,6 \\
\hline 2 & $\begin{array}{l}\text { Ideologi Politik (X2) terhadap } \\
\text { Transaksional Politik (Y) }\end{array}$ & 0,69 & Kuat & $47,6 \%$ & 4,208 & 29,3 \\
\hline 3 & $\begin{array}{l}\text { Komunikasi Politik (X1) dan } \\
\text { Ideologi Politik (X2) terhadap } \\
\text { Transaksional Politik }\end{array}$ & 0,67 & Kuat & $44,8 \%$ & 4,161 & 32,7 \\
\hline
\end{tabular}

Sumber : Hasil Pengolahan Data SPSS IBM Versi 21, 2018

berbeda, dan jalan tengah dari ketidaksukaan masyarakat atas fenomena ini adalah dengan jalan menerima politik uang. Artinya, money politic pada sisi yang bersebrangan juga menjadi bagian dari perlawanan masyarakat atas rendahnya kualitas calon. Tentunya pemilukada sebagai sebuah politik baru di Indonesia harus memberikan manfaat pada masyarakat (Agustino \& Yusoff, 2010). Dalam konteks ini maka, kampanye tolak politik uang agak tertinggal dalam perspektif substansial budaya, sosial politik masyarakat yang sekarang bergerak pada persepsi yang berbeda tentang money politic dengan penyelenggara pemilu. Realitas yang dibangun dan disajikan kepada publik sarat dengan kepentingan dan bagi-bagi kekuasaan (Berger, 1976). Politik uang saat ini seolah-olah tidak mendistorsi demokrasi, tidak lagi di persimpangan antara kepentingan kepala daerah dan kepentingan masyarakat ataupun menghilangkan makna terhadap legitimasi kekuasaan. Pandainya elit politik memainkan media massa, turut memberikan kontribusi pada branding penguatan legitimasi kekuasaan tersebut (Anshari, 2013). Politik uang menusuk esensi demokrasi cukup dalam, membentuk momen-momen krisis pada derajat pengaruh yang berbeda-beda di setiap sendi-sendi dasar kehidupan masyarakat pemilih baik langsung maupun tak langsung; menciptakan kekuasaan

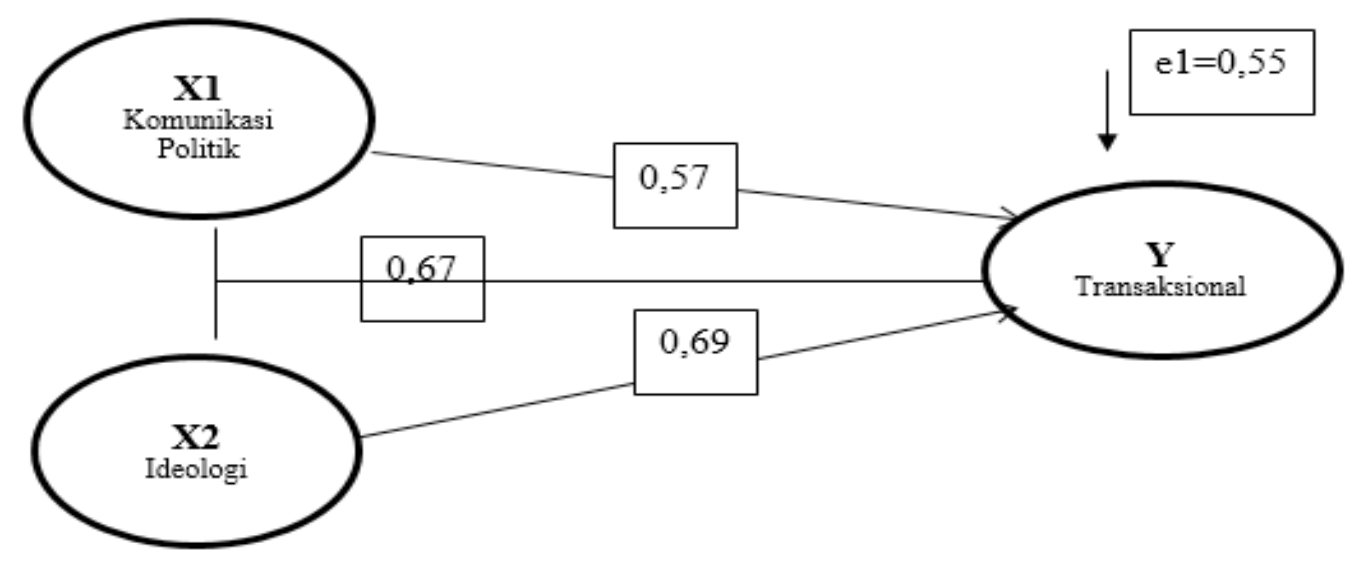

Gambar 1 Diagram Jalur X1,X2 terhadap Y

Sumber: Hasil Peneliian, 2018 
material dan kesadaran sosial yang dimobilisasi, namun politik uang juga telah mengambil peran sentral sebagai penarik dan ketertarikan pemilih untuk berpartisipasi di dalamnya.

Penelitian ini menunjukkan bahwa sebagian besar politisi menyadari bahwa dalam berpolitik membutuhkan biaya, namun masih menjadi hal yang lumrah bahwa pemenuhannya dipenuhi dengan cara yang salah. Penelitian ini juga menemukan bahwa, sebagian besar uang yang diperoleh dihabiskan untuk kampanye dan proses pemenangannya untuk mengatur peristiwa politik yang berfungsi untuk menghubungi pemilih melalui berbagai metode seperti iklan, aksi unjuk rasa, dan pertemuanpertemuan politik, pembelian suara, pembelian kandidat, memanipulasi administrasi pemilu dan membeli upaya pemenangan perkara pemilu. Selain itu, penelitian ini mengungkapkan bahwa meskipun ada kekhawatiran di sebagian besar politisi atas pembelian suara namun mereka tidak bisa menghindari praktek-praktek tersebut untuk mempengaruhi pemilih melalui pengaruh uang.

Secara keseluruhan, data yang dikumpulkan menunjukkan bahwa partai dan kandidat politik mengatakan bahwa mereka mendapatkan dana politik dari sumber yang sah. Sumbersumber ini meliputi kegiatan-pihak terkait, seperti acara-acara penggalangan dana dan iuran keanggotaan; kontribusi dari sektor swasta; skema pendanaan publik; sumbangan individu dan lain sebagainya. Demikian pula, sebagian besar pengeluaran partai dan kandidat merasa bahwa uang yang mereka keluarkan masih masuk dalam kategori biaya politik yang diperlukan dalam suatu proses politik. Namun demikian, sulit bagi penelitian ini untuk menjelaskan secara umum bahwa proses pendanaan dan pengeluaran dalam proses pemilukada yang terjadi berhubungan dengan struktur organisasi yang kuat, jujur dan terbuka terhadap pendapatan sebenarnya. Berdasarkan Peraturan Komisi Pemilihan Umum Nomor 4 Tahun 2017 tentang Fenomena politik pemilu yang teramati saat ini di Kota Serang tak bisa dilepaskan dari gambaran kekuasaan yang dapat dianalogikan seperti uang dalam kehidupan ekonomi untuk mengukur suatu transaksi dan perubahan. Kekuasaan politik yang terjadi menjadi linier dengan peranan uang. Maka tak heran jika kekuasaan dan uang seakanakan memiliki fungsi sosial yang sama, yakni suatu fungsi yang menjadi acuan cara-cara bertingkah laku memenuhi kebutuhan hidup individu, keluarga, kelompok, masyarakat dan organisasi. Kiranya inilah yang menjadi dasar dari realitas politik uang (money politic) dalam praksis politik pemilu di Kota Serang, Banten yang menganggap konsepsi kekuasaan politik dalam proses politik sejalan dengan peranan uang dalam proses ekonomi. Selain dari itu bagi-bagi uang sebagai sebuah pemaknaan lazim di masyarakat (Hastuti et al., 2013), menjadi sebuah pekerjaan sulit untuk kemudian membebaskan pesta demokrasi di Indonesia dari praktek transaksional money politic.

Fenomena politik uang secara masif terjadi pada seluruh tingkatan pemilu, terutama pemilukada. Masyarakat dan para calon sama sama tahu, siapa dan bagaimana proses praktek jual beli suara itu terjadi. Hal ini menjadi salah satu sebab demokrasi berbiaya tinggi dan terbentuknya mata rantai kartel politik, dimana votes (suara) menjadi sebuah komoditas yang bisa dijual. Uang dalam proses politik pemilu seperti dua sisi dalam satu mata uang. Pertama, menjelaskan kampanye sebagai amanat undangundang yang mesti dilaksanakan dengan segala konsekuensi biayanya yang mesti dikeluarkan dalam rangka memenuhi hak atas informasi yang dibutuhkan masyarakat pemilih. Disisi yang lain, biaya yang cukup besar yang sudah dikeluarkan pada seluruh kinerja kampanye mendorong kebutuhan lainnya, yakni calon kepala daerah mesti memastikan harapan pada derajat tertentu untuk menang dan dipilih oleh masyarakat pemilih. Dalam konteks ini sangat jelas sekali bila ideologi mengalami pergeseran dan perubahan karena kecenderungan pada pemikiran pragmatisme (Makhasin, 2016), rasionalitas akan beban dan biaya yang begitu besar serta kurang sigapnya partai dalam akan melahirkan fenomena yang sama pada pemilukada yang akan datang.

\section{SIMPULAN}

Komunikasi Politik $\left(\mathrm{X}_{1}\right)$ dan ideologi (X2) partai politik merupakan faktor yang penting dan memiliki peran yang sangat signifikan dalam pilwalkot Serang 2018-2023. Akan tetapi adanya elit politik makaideologi partai kemudian bersumber pada finansial, maka semuanya akan tergantung pada janji dan nilai transaksi politik 
yang diandalkan. Oleh karenanya, lingkaran pada kualitas ini akan menghadirkan pada kualitas pemimpin yang akan terikat pada nilai konsensus semata. Korelasi antara Komunikasi politik uang $\left(\mathrm{X}_{1}\right)$ terhadap transaksional politik (Y) terbilang cukup kuat, yakni 0,57 , artinya komunikasi Politik memiliki pengaruh langsung terhadap transaksional politik. Demikian pula Korelasi X2 (Ideologi) terhadap Y (transaksional politik) adalah $(0,69)$ artinya parpol memiliki kekuatan dan idealisme pada tataran awal, akan tetap ketika berbenturan dengan kesiapan sumber daya calon kepala daerah maka memiliki kecenderungan pada kekuatan finansial. Sedangkan korelasi antara Komunikasi Politik $\left(\mathrm{X}_{1}\right)$, Ideologi $\left(\mathrm{X}_{2}\right)$, terhadap Transaksional Politik (Y) adalah kuat $(0,67)$, artinya kekuatan transaksional yang dilakukan oleh para elit sudah sangat masiv dan memiliki peran yang sangat kuat. Praktek politik uang adalah kekuatan suap yang telah sekian lama terjadi dan sekarang telah menjadi kekuatan budaya. Politik uang dianggap kejahatan ketika ia dapat dijadikan ancaman rivalitas pasangan calon dalam Pilwalkot dalam kerangka pemenangan pasangan calon. Di sisi lain, politik uang telah dianggap bagian dari proses kontestasi yang wajar. Bagian dari kepantasan yang mesti dimiiki oleh calon kepala daerah, jika tidak dipenuhi, boleh jadi ia dianggap tidak kompeten dari sisi kemampuan finansial. Politik uang mendapat daya dukung dari adanya karakteristik kekerabatan dan kekeluargaan dalam masyarakat kota Serang yang lekat dalam proses usung-mengusung di Pilwalkot Serang. Kekerabatan dan kekeluargaan memberi tempat bagi praktek politik uang yang secara budaya tidak dianggap politik uang, tetapi bagian dari kepercayaan keluarga untuk berbagi sesuatu, bahkan untuk pertukaran yang lebih besar seperti perwakilan keluarga pasangan calon yang memberikan penawaran memperbaiki jalan suatu perumahan jika masyarakat perumahan terebut mau memilih pasangan calon tertentu. Politik uang di sisi lain dianggap sebagai satu-satunya cara yang paling adil bagi pemilih atas sinisme mereka karena ketidakpercayaan pemilih terhadap parpol, janji kampanye dan kebiasaan selama ini bahwa setelah menjabat tidak pro masyarakat. Dengan kondisi seperti ini maka kader partai harus tegas dalam melawan mekanisme yang dianggap menghambat pada penentuan arah politik terutama dalam penentuan kandidat yang ada. Selain itu penyelesaian penentuan pimpinan yang berlandaskan pada kekuatan finansial tidak bisa parsial. Ia mesti melihat faktor-faktor lain secara komprehensif, seperti kaderisasi parpol, pendidikan politik yang dijalankan dan kemampuan lembaga pendidikan untuk mengolahnya sebagai simbol perlawanan.

\section{DAFTAR PUSTAKA}

Agustino, L., \& Yusoff, M. A. (2010). Politik lokal di Indonesia: dari otokratik ke reformasi politik. Jurnal Ilmu Politik, 21, 2010.

Ahmad, I. (2015). Pilar demokrasi kelima: politik uang: realitas konstruksi politik uang di Kota Serang, Banten. Deepublish.

Ahmad, I., Gumelar, R. G., \& Mukhroman, I. (2017). Komunikasi pemasaran politik dan pengaruhnya terhadap seleksi calon pemimpin pada partai politik (Survei Penelitian pada PDIP Kab. PandeglangLebak Provinsi Banten). Prosiding Magister Ilmu Komunikasi, 1(1).

Ali, M. (2003). Money politics dalam pilkada. Jurnal Hukum, 12(2), 227-234.

Aminuddin, M. F., \& Attamimi, N. H. (2019). From retail to grocery: money politics in 2014 Indonesian legislative election. Politik Indonesia: Indonesian Political Science Review, 4(1), 99-120. https://doi. org/10.15294/ipsr.v4i1.12609

Andriana, N. (2016). Arti penting ideologi bagi partai politik. Jurnal Penelitian Politik, $7(2), 8$.

Anshari, F. (2013). Komunikasi politik di era media sosial. Jurnal Komunikasi, 8(1), 91-101.

Berger, P. L. (1976). Pyramids of sacrifice: political ethics and social change. Peter L. Berger. American Journal of Sociology, 81(5). https://doi.org/10.1086/226202

Creswell, J. W. (2014). A concise introduction to mixed methods research. New York: SAGE publications.

Ghozali, I. (2006). Aplikasi analisis multivariate dengan program spss. In Analisis Multivariate dengan Program SPSS.

Hastuti, F., Widayati, W., \& Harsasto, P. (2013). Politik uang dalam pemilukades 
Desa Cangkring Dan Desa Dawuahan, Kecamatan Talang, Kabupaten Tegal 2012. Journal of Politic and Government Studies, 2(3), 396-410.

Huda, N. (2011). Penyelesaian sengketa pemilihan bupati Bengkulu Selatan di mahkamah konstitusi. Jurnal Hukum IUS QUIA IUSTUM, 18, 81-106.

Kaid,L.L.2004.(n.d.). Political communication.

Kenterelidou, C. (2005). Public political communication and Medi. The case of contemporary Greece . Political Communication, 1-23.

Kumorotomo, W. (2009). Intervensi parpol, politik uang dan korupsi: tantangan kebijakan publik setelah pilkada berlangsung. Konferensi Administrasi Negara, 32, 1-18.

Lasswell, H. (1948). The structure and function of communication in society. New York.

Makhasin, L. (2016). Orientasi ideologi dan pragmatisme politik model pembentukan koalisi dalam pilkada serentak di Jawa Tengah 2015. Jurnal Ilmu Sosial Dan Ilmu Politik, 19(3), 234. https://doi. org/10.22146/jsp.15685

Moleong, L. J. (2018). Metodologi penelitian kualitatif, cet. In XI. Bandung: Remaja Rosdakarya.

Muhidin, S. A., \& Abdurahman, M. (2007). Analisis korelasi, regresi, dan jalur dalam penelitian. Bandung: Pustaka Setia

Nimmo, D. D. (1978). Political communication and public opinion in America. Goodyear Publishing Company.

Pratikno. (2007). Calon independen, kualitas pilkada dan pelembagaan parpol. Jurnal Ilmu Sosial Dan Ilmu Politik, 10(3), 415438.

Reuter, T. (2015). Political parties and the power of money in Indonesia and beyond. TRaNS: Trans-Regional and -National Studies of Southeast Asia, 3(2), 267-288. https://doi.org/10.1017/trn.2014.23

Solihah, R. (2016). Politik transaksional dalam pilkada serentak dan implikasinya bagi pemerintahan daerah di Indonesia. The POLITICS: Jurnal Magister Ilmu Politik Universitas Hasanuddin, 97-109.

Sugiyono. (2012). Metode penelitian kuantitatif, kualitatif dan $r$ \& d. Bandung:Alfabeta.

Sugiyono. (2018). Metode penelitian kuatintatif , kualitatif dan $r$ \& d. Bandung: Alfabeta

Sulaeman, A. (2017). Demokrasi, Partai Politik Dan Pemilihan Kepala Daerah. CosmoGov, 1(1), 12. https://doi.org/10.24198/ cosmogov.v1i1.11857

Sulaiman, A. I. (2013). Komunikasi politik dalam demokratisasi. Observasi, 11(2), 119-132.

Surbakti, R. (2007). Memahami ilmu politik. Jakarta: Grasindo.

Susanto, E. H. (2013). Dinamika komunikasi politik dalam pemilihan umum. Jurnal Kajian Komunikasi, 1(2), 163-172. https:// doi.org/10.24198/jkk.vol1n2.6 